\title{
CUERPO Y SURREALISMO: SOBRE EL QUIASMO EN LA TORTUGA ECUESTRE DE CÉSAR MORO Y UN PERRO ANDALUZ DE LUIS BUÑUEL ${ }^{*}$
}

\author{
José Carlos Cabrejo CobIÁN** \\ Universidad de Lima \\ jcabrejo@ulima.edu.pe
}

Recibido: 5/7/2021 Aceptado: 25/7/2021

doi: https://doi.org/10.26439/contratexto2021.n036.5276

RESUMEN. Este ensayo tiene como objetivo explorar cómo el poemario La tortuga ecuestre de César Moro, escrito entre 1938 y 1939, y el cortometraje Un perro andaluz de Luis Buñuel, que vio la luz en el año 1929, dos obras emblemáticas de la vanguardia surrealista, abordaron la representación icónica del cuerpo. Este fenómeno es analizado, por un lado, desde la perspectiva del quiasmo hallada en la obra del filósofo Maurice Merleau-Ponty; y, por otro, desde las semióticas generativa (Algirdas Julien Greimas y Joseph Courtés) y tensiva (Jacques Fontanille y Claude Zilberberg). La conclusión a la que se llega es que dichas obras confirman que el discurso surrealista en la poesía y el cine toma a través de la iconicidad una conciencia del quiasmo al enfocar el cuerpo y el mundo como una sola entidad, de modo íntegro y unitario.

PALABRAS CLAVE: surrealismo / César Moro / Luis Buñuel / cuerpo / Maurice Merleau-Ponty

\section{BODY AND SURREALISM: ON THE QUIASM IN CÉSAR MORO'S THE EQUESTRIAN TURTLE AND LUIS BUÑUEL'S AN ANDALUSIAN DOG}

ABSTRACT. This essay explores how the poetry book The Equestrian Turtle by César Moro, written between 1938 and 1939, and the short film An Andalusian Dog by Luis Buñuel, released in 1929, two emblematic works of the surrealist avant-garde, addressed the iconic representation of the body. On the one had, this phenomenon

\footnotetext{
* El ensayo se basa en una investigación que pronto será publicada.

** Magíster en Lengua y Literatura por la Universidad Nacional Mayor de San Marcos (véase: http://orcid. org/0000-0002-8388-4301).
} 
is analyzedfrom the perspective of the chiasm found in the work of the philosopher Maurice Merleau-Ponty; on the other, from generative (Algirdas Julien Greimas and Joseph Courtés) and tensive (Jacques Fontanille and Claude Zilberberg) semiotics. The conclusion reached is that these works confirm that the surrealist discourse in poetry and cinema takes an awareness of chiasm through iconicity, by focusing the body and the world as a single entity, in an integral and unitary way.

KEYWORDS: surrealism / César Moro / Luis Buñuel / body / Maurice Merleau-Ponty

\section{CORPO E SURREALISMO: SOBRE 0 QUIASMO EM LA TORTUGA ECUESTRE DE CÉSAR MORO E UN PERRO ANDALUZ POR LUIS BUÑUEL}

Resumo. Este ensaio tem como objetivo explorar como duas obras emblemáticas da vanguarda surrealista: o livro de poesia La tortuga ecuestre de César Moro, escrito entre 1938 e 1939, e o curta-metragem Un perro andaluz de Luis Buñuel, lançado em 1929, e abordaram a representação icônica do corpo. Esse fenômeno é analisado, por um lado, sob a ótica do quiasma da obra do filósofo Maurice Merleau-Ponty; de outro, a partir das semióticas gerativa (Algirdas Julien Greimas e Joseph Courtés) e tensiva (Jacques Fontanille e Claude Zilberberg). A conclusão a que se chega é que essas obras confirmam que o discurso surrealista na poesia e no cinema toma consciência do quiasma pela iconicidade, ao enfocar o corpo e o mundo como uma entidade única, de forma integral e unitária.

PALAVRAS-CHAVE: surrealismo / Cesar Moro / Luis Buñuel / corpo / Maurice Merleau-Ponty 


\title{
INTRODUCCIÓN
}

Un aspecto esencial de la vanguardia surrealista fue la representación del cuerpo. Dicho tópico es explorado en el cortometraje francés Un perro andaluz (Un chien andalou, 1929), dirigido por el cineasta español Luis Buñuel, y en el poemario La tortuga ecuestre, del peruano César Moro. Esta es una de las obras surrealistas de las más prestigiosas en Latinoamérica, con versos escritos entre los años 1938 y 1939, pero publicados en 1957. A pesar de que su poesía fue prácticamente ignorada en su época, inclusive tomando en cuenta que dicho poeta formó parte del grupo liderado por André Breton en París, obtuvo una atención creciente hasta la actualidad:

\begin{abstract}
a la vez por la personalidad exigente, fundamentalmente libre del poeta y por la originalidad extrema de su poesía. Este descubrimiento se realizó progresivamente gracias a ediciones póstumas - La tortuga ecuestre, Los anteojos de azufre, Amour à mort, Ces poèmes..., que revelaron una parte importante de sus textos y permitieron investigaciones aún más profundas sobre su poesía- [...] es posible promover y difundir una obra de difícil acceso para que tenga, por fin, una justa consagración gracias a la devoción de un grupo de admiradores incondicionales que, como lo escribe Julien Gracq a propósito de Mallarmé, estarían "listos para morir por él". Es el deber que cumplieron con una magnífica decisión, a diferentes niveles, André Coyné, Emilio Adolfo Westphalen, Américo Ferrari, Julio Ortega, Ricardo Silva-Santisteban. Es la misma devoción que empujó a una nueva generación de universitarios - Martha Canfield, Mariela Dreyfus, Yolanda Westphalen Rodríguez, Gaëlle Hourdin, entre otros- a concentrar sus investigaciones en las diversas facetas de una obra que presenta enormes problemas metodológicos. (Lefort, 2015, pp. XXIX-XXX)
\end{abstract}

En el marco de la vanguardia poética peruana, César Moro fue un poeta que, al igual que Emilio Adolfo Westphalen en una obra como Las ínsulas extrañas (1933), o Xavier Abril, con los "poemas turistas" que escribió entre 1926 y 1927 y que fueron incluidos en el poemario Hollywood (1931), se aproximó más al surrealismo, a diferencia de otros poetas como César Vallejo, Carlos Oquendo de Amat o Alberto Hidalgo, por mencionar a algunos vates importantes del periodo. Entre los años 1938 y 1939, los mismos en los que Moro creó los poemas de La tortuga ecuestre, escribió las "Cartas a Antonio". Estas, como se referirá hacia el final del artículo, muestran coincidencias importantes con dichos poemas. Sin embargo, el peruano solo publicó en vida un libro llamado Le château de grisou (1943) y dos plaquettes: Lettres d'amour (1944) y Trafalgar Square (1954), "tres obras en francés de tirada limitada, y que casi no salieron del círculo de sus amigos" (Coyné, 2015, p. XLVI). En contraste con las "Cartas..." y La tortuga ecuestre, su único poemario íntegramente escrito en español, la poesía en francés de Moro tiende a una atenuación de lo surreal, y resulta más atractiva con respecto a cómo "devora" aquella lengua del país europeo por medio de rasgos propios de la lengua española, tal como lo plantea 
Fernández Cozman en su libro César Moro, ¿un antropófago de la cultura? (2012), y desde la perspectiva del Manifiesto antropófago (1928) de Oswald de Andrade.

Si saltamos a este siglo, descubriremos que se han dedicado a Moro distintos eventos internacionales, como el coloquio "César Moro y el surrealismo en América Latina", realizado el 4, 5 y 6 de diciembre del año 2003 por la Facultad de Letras y Ciencias Humanas de la Universidad Nacional Mayor de San Marcos del Perú, y el congreso "Amor hasta la muerte: la poesía pasional de César Moro", que se llevó a cabo del 21 al 23 de septiembre del 2016, organizado por la Academia Peruana de la Lengua.

Por su parte, el cortometraje Un perro andaluz fue referido por André Breton "como parte constituyente del surrealismo" (como se citó en Richardson, 2006, p. 27). Dicha obra no solo definió algunas de las marcas de estilo que aparecerían en los siguientes filmes de uno de los cineastas más influyentes de España y de toda la historia del cine. También contribuyó a una experimentación del montaje, en la que la discontinuidad entre un encuadre y otro, como ocurre en la forma absurda con que las imágenes se suceden en los sueños, se haría notoria tanto en ciertos modos expresivos del videoclip como en el lenguaje autoral de realizadores como David Lynch, Alejandro Jodorowsky o Maya Deren.

Los textos literarios, como el poemario La tortuga ecuestre, así como los textos fílmicos, como Un perro andaluz, tienen en común una naturaleza icónica, a pesar de que obedecen a una construcción diferente. Según Blanco (2009), la literatura plasma diversos códigos:

En el caso del texto literario se introducen a través de la palabra: códigos visuales (formas, colores, espacios...), códigos sonoros (ruidos, melodías, gritos...), códigos táctiles (consistencias, rugosidades, lisuras...), códigos olfativos (olores, perfumes...) y códigos gustativos (sabores diversos). Pero no solo ellos aparecen en el texto literario, sino también códigos más sofisticados y de mayor alcance, como los códigos de los gestos, los códigos del comportamiento ordinario, los códigos emblemáticos (banderas, símbolos, logotipos, monogramas, señales de todo tipo), los códigos del relato y tantos otros. (p. 185)

Alguna vez, el propio André Breton llegó a considerar a "las inspiraciones verbales como infinitamente más ricas de sentido visual, infinitamente más sólidas para la vista que las imágenes visuales propiamente dichas" (como se citó en Alquié, 1974, p. 36). Es posible apreciar ello en el poemario de César Moro por medio de códigos de órdenes visuales ("Te veo en una selva fragorosa", en la parte III del poema "El fuego y la poesía", 2002, p. 89), sonoro (“Pisoteando el mundo... que gime...", en el poema "La leve pisada del demonio nocturno", 2002, p. 83), táctil (“Como una sombra de mano en un instrumento fantasma", en el poema "El mundo ilustrado", 2002, p. 74), olfativo ("El olor fino solitario de tus axilas", en el poema "El olor y la mirada", 2002, p. 70) y gustativo ("Donde el crimen pernocta y bebe el agua clara / De la sangre más caliente del día" en la parte I del poema “El fuego y la poesía”, 2002, p. 87). 
Hay una condición sincrética en el texto literario como en el fílmico. Blanco (2009) indica que en la constitución del texto cinematográfico pueden ingresar códigos de orden visual o sonoro sin que sean necesariamente textualizados por medio de la lengua. Para él "la lengua vuelve a aparecer, en el estadio actual del desarrollo del cine, en el texto fílmico; pero ahora al lado de otros códigos y en interacción con ellos" (p. 186). En Un perro andaluz, una película muda, es posible encontrar la lengua en los carteles que se suceden durante el cortometraje, con letras blancas sobre un fondo de color negro, a través de expresiones en francés como "En primavera", "Ocho años después", etcétera. El código visual se manifiesta por medio de imágenes en movimiento; por ejemplo, en la secuencia del personaje que corta con una navaja el ojo de una mujer. Del mismo modo, se presentan pasajes sonoros del drama musical Tristán e Isolda de Richard Wagner, usualmente añadidos a la proyección del cortometraje.

Más allá de sus diferencias, ambas obras comparten una visualidad del cuerpo. Siguiendo a Blanco (2009), se identifica una icónica literaria y una icónica cinematográfica:

Es claro que la icónica literaria y la icónica cinematográfica son notablemente diferentes. Mientras que los elementos icónicos del signo visual son captados por los órganos de la visión, los elementos icónicos del signo lingüístico son captados por los órganos de la representación, de naturaleza psíquica y no visual. En eso radica la diferencia entre un paisaje descrito con palabras y un paisaje mostrado con imágenes. Para lograr la iconicidad literaria, el texto lingüístico se ve obligado a acudir a recursos retóricos como la metáfora, la comparación, la metonimia, la hipotiposis, etcétera. La iconicidad cinematográfica es directamente visual, despojada de giros retóricos, inmediata. (p. 190)

Sin embargo, es importante señalar que, como se verá más adelante, en el cine sí existen recursos retóricos, mayormente de tipo metafórico y metonímico. Para Courtés (1997), el orden icónico es parte del ámbito figurativo:

Calificamos de figurativo todo significado, todo contenido de una lengua natural y, más ampliamente, de todo sistema de representación (visual, por ejemplo) al que corresponde un elemento en el plano del significante (o de la expresión) del mundo natural, de la realidad perceptible. Será, pues, considerado como figurativo, en un universo dado (verbal o no verbal), todo lo que puede estar directamente relacionado con uno de los cinco sentidos tradicionales: la vista, el oído, el olfato, el gusto y el tacto; en pocas palabras, todo lo que depende de la percepción del mundo exterior. (p. 238)

Tomando en cuenta lo afirmado por Blanco (2009) y Courtés (1997), lo icónico, al margen de aparecer inmerso en un mundo verbal (como lo es un poemario) o no estrictamente verbal (como lo son las producciones audiovisuales), tiene como punto de partida lo figurativo, aquello que es captado por cualquiera de nuestros sentidos. A partir de esa perspectiva, se puede distinguir entre lo figurativo icónico y lo figurativo abstracto: 
Lo figurativo icónico es aquello que produce la mejor ilusión referencial [...], que parece como lo más próximo a la realidad; cuando É. Zola describe El vientre de París, sentimos como una fuerte impresión de semejanza — de iconicidad, diríamos en términos semióticos - aunque solo sea por la multitud de los pequeños detalles concretos que se destacan. Lo figurativo abstracto es, por el contrario, lo que solo incluye un número mínimo de rasgos de la "realidad" [...] la diferencia se funda únicamente en un número más o menos mayor de rasgos, de elementos constituyentes. (Courtés, 1997, pp. 246-247)

Lo arriba citado indica que para Courtés no solo la descripción detallada que hace Émile Zola en su novela sea una clara representación de lo figurativo icónico, sino también, por ejemplo, una fotografía. Un perro andaluz y La tortuga ecuestre, por sus numerosos detalles visuales, son una muestra representativa de cómo una obra surrealista, literaria o no, cinematográfica o no, puede caracterizarse por su orientación hacia lo figurativo icónico en detrimento de lo figurativo abstracto, sobre todo en lo que respecta a lo corporal.

A partir de esta coincidencia, este ensayo tiene como objetivo analizar la forma en que ambos textos, poético y cinematográfico, desarrollan una representación icónica del cuerpo. Las figuras que remiten a la corporeidad humana y animal abundan tanto en la poesía como en el cine surrealistas, pero si hay dos obras esenciales en darle una presencia figurativa central al cuerpo, esas son La tortuga ecuestre y Un perro andaluz.

Este ensayo concluye que dichas obras de Moro y Buñuel son emblemáticas de cómo el surrealismo en la iconicidad de sus vertientes poética y cinematográfica posee una conciencia del quiasmo, de la unidad del cuerpo con el mundo. ¿A qué nos referimos con el quiasmo? La obra de Maurice Merleau-Ponty exhibe una preocupación central por el cuerpo y se impone, según Ramírez (2013), una "filosofía del quiasmo". Para este autor, la filosofía del francés, partiendo de dualidades importantes en los inicios de la filosofía, como alma y cuerpo, materia y espíritu o experiencia y razón (capítulo II, subtítulo 1 , párrafo 1), plantea trascender la dicotomía. Propone pensar en la relación y entrelazamiento de sus partes, es decir, en el ser de la dualidad:

Pensar la dualidad como tal significa no pensarla ni en función de los elementos que la componen (dualismo metafísico), de unas entidades contrapuestas o yuxtapuestas, ni tampoco en función de una unidad trascendente, de una tercera entidad -ya se le ubique como anterior al desdoblamiento (monismo teológico-metafísico), o ya como resultado de su reunificación postrera y extrínseca (monismo dialéctico)- Merleau-Ponty dice que lo que debemos pensar es la relación como tal, lo que hay entre: la realidad de este ser intermedio, la figura y el sentido de la mediación; el sí mismo de lo que está en medio: l'entrelacs. No el alma y el cuerpo, o la experiencia y el pensamiento - es decir, la dicotomía-; tampoco el alma o el cuerpo, la experiencia o el sentido —esto es, la exclusión-; menos el Espíritu, el Saber -la supuesta síntesis-. Lo que debemos pensar es el alma-y-el cuerpo, 
la experiencia-y-el sentido; es decir, la conjunción en cuanto tal, el proceso de la diferenciación, la actualidad del devenir, el ser de la dualidad. (Capítulo II, subtítulo 1, párrafo 2)

\section{LOS CAMINOS DEL QUIASMO}

Ramírez (2013) plantea que tanto en el campo de la retórica, donde el quiasmo se entiende como la "distribución simétrica o cruzada de las mismas palabras en dos frases contiguas" (Garrido Gallardo, 2009, p. 152), como en el de la óptica (quiasma), es posible reconocer la misma dinámica: el entrecruzamiento de dos cosas cualesquiera. Él refiere que Merleau-Ponty, aunque no desarrolle en su obra una conceptualización específica del quiasmo, hace referencia a él constantemente, entendiéndolo como una existencia propia de lo dual, que no ha sido pensada a través de las figuras filosóficas tradicionales como el monismo, el dualismo o la dialéctica (capítulo Il, subtítulo 1, párrafos 3 y 4).

En efecto, el exégeta de la obra de Merleau-Ponty indica que el quiasmo no puede ser considerado ni un dualismo ni un monismo puro, sino un monismo dualista (un ser que se diferencia) y un dualismo monista (una diferencia solidaria). Del mismo modo, afirma que permite entender la dualidad en términos de reciprocidad, relatividad, entrecruzamiento, complementariedad, superposición, encabalgamiento, empotramiento, reversibilidad o mutua referencia (Ramírez, 2013, capítulo Il, subtítulo 1, párrafos 12 y 13).

Asumir la existencia de un cuerpo y un mundo como unidad nos lleva a definirla como un monismo dualista o como un dualismo monista, como un quiasmo, en el que es posible encontrar, en palabras de Ramírez (2013), "yo-mi cuerpo-y-mi mundo", dicho de otro modo, un ser del cuerpo inseparable del ser del mundo (capítulo III, punto A, subtítulo 1, párrafos 5 y 7 ).

Para Merleau-Ponty (1993), "el cuerpo es el vehículo del ser-del-mundo" (p. 100), y, de la misma manera, el filósofo afirma que el quiasmo se define así:

[Un] intercambio de mí con el mundo, del cuerpo fenoménico con el cuerpo "objetivo", de lo que percibe con lo percibido: lo que comienza como cosa termina como conciencia de la cosa, lo que comienza como "estado de conciencia" termina como cosa. (Merleau-Ponty, 2010, p. 191)

En Fenomenología de la percepción (1993), Merleau-Ponty aseveró que nos hallamos "cogidos en el mundo y no conseguimos desligarnos del mismo para pasar a la consciencia del mundo" (p. 27). Según el autor francés, el quiasmo se encuentra asociado a un cuerpo que se encuentra en el mundo y a un mundo que está en el cuerpo:

la inserción del mundo entre las dos hojas de mi cuerpo, la inserción de mi cuerpo entre las dos hojas de cada cosa y del mundo [...] la idea del quiasmo, es decir: toda relación con el ser es simultáneamente aprehender y ser aprehendido, la 
aprehensión es aprehendida, está inscripta y se inscribe en el mismo ser que ella aprehende. (Merleau-Ponty, 2010, pp. 232 y 234)

En ese sentido, es importante destacar aquella "carne del mundo" que para MerleauPonty (2010) es esa "indivisión de ese Ser sensible que yo soy, y de todo el resto que se siente en mí" (p. 225). Es un fenómeno en el que "las cosas me tocan como yo las toco y me toco" (p. 230), y que Abbagnano (2008) define como una "sustancia viva que es común al cuerpo del hombre y a las cosas del mundo y que constituye a la vez el objeto y el sujeto de la experiencia humana" (p. 142).

\section{CUERPOS DE POESÍA Y CINE}

El símil es una figura retórica que podemos tomar como un primer modo de acceso al quiasmo presente en estas dos obras surrealistas. En el poema "Un camino de tierra en medio de la tierra", figuras corporales como la /frente/ o el /rostro/ 1 son planteadas en términos de semejanza con espacios arquitectónicos (/castillo/) o fenómenos que se desprenden del cielo o se ubican en él (/nieve/, /noche/):

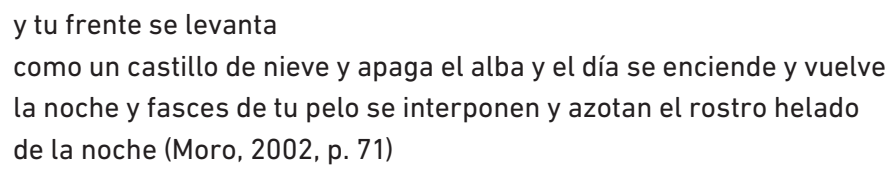

Por un lado, se transfieren características de dichos espacios y fenómenos a figuras del cuerpo; por otro, estas se imponen como elementos esencialmente integrados al mundo: se comprenden como un solo ser. La /frente/ posee la capacidad de dar fin al amanecer, así como nacimiento al día o a la noche ("apaga el alba y el día se enciende y vuelve / la noche"), mientras que algunas dimensiones del pelo son capaces de entrar en contacto violento con el cielo nocturno, caracterizado por una gélida faz ("Y fasces de tu pelo se interponen y azotan el rostro helado / de la noche"). El cuerpo da vida al mundo, y el mundo a su vez es un cuerpo.

En la secuencia inicial de Un perro andaluz un personaje interpretado por el mismo Luis Buñuel articula un singular símil. Al comienzo, se le ve sacando filo a una navaja y mira a continuación una luna llena a través de la cual se ve el paso de unas nubes. Después, se le ve acercando su navaja al ojo de una mujer. En encuadres cerrados, vemos cómo dicho ojo es cortado por la navaja. La semejanza icónica entre las nubes y la navaja, y entre la luna llena y el ojo de la mujer, enfoca a dicha luna como presencia

1 Es común en el modelo del recorrido generativo que las figuras se grafiquen con barras diagonales a los costados. 
que siente esos fenómenos celestiales de la misma manera en que aquel globo ocular siente el filo de aquel objeto.

En otra secuencia de la película se usa el recurso de la disolvencia, en el que se transita de modo gradual de un encuadre a otro, para mostrar en secuencia tres imágenes: una de un plano de detalle de una mano con un agujero en la palma, de la cual salen hormigas; otra de la axila de una mujer; y finalmente la que muestra un erizo de mar. Dicha disolvencia crea un quiasmo muy singular, dado que su progresión visual hace que las hormigas que salen de la mano por un momento se crucen, se hibriden, se fusionen, con la imagen de la axila, y esta haga lo mismo a continuación con el encuadre del erizo de mar: las visiones del cuerpo humano se hacen una sola con las de los animales. Cinematográficamente, se tornan por momentos en un solo ser. Se identifican quiasmos icónicos del cuerpo humano con lo animal.

Esos mismos quiasmos icónicos de lo corpóreo, con aquello que pueda rodearlo en el mundo, se hallan en el poema de Moro "Vienes en la noche con el humo fabuloso de tu cabellera". Por ejemplo, en el siguiente fragmento:

\author{
Y rodar por la pendiente de tu cuerpo \\ Hasta tus pies centelleantes \\ hasta tus pies de constelaciones gemelas \\ En la noche terrestre \\ Que te sigue encadenada y muda \\ Enredadera de tu sangre \\ Sosteniendo la flor de tu cabeza de cristal moreno (Moro, 2002, p. 81)
}

Nótese la manera en la que el yo del poema recorre el cuerpo del objeto de deseo de modo descendente ("Y rodar por la pendiente de tu cuerpo") $)^{2}$. Justamente, entre los rasgos poéticos a destacar en el surrealismo, se encuentran las "aproximaciones insólitas":

[Estas se cimentan] en la capacidad que tiene la imaginación de captar relaciones que la razón jamás hubiera sospechado. La imagen resultante tiene un evidente carácter arbitrario, y lo arbitrario, como dice Breton en el "Primer Manifiesto del Surrealismo", tiene una enorme dosis de contradicción. En este sentido, las aproximaciones insólitas constituyen un símbolo de la unión de los contrarios, de la identidad de los opuestos. (Pellegrini, 2012, p. 24)

2 Valga aclarar que cuando referimos al "yo", no lo hacemos en función del yo autor, quien en este caso es César Moro. Precisamente, Blanco (2009) destaca que el discurso propone una representación simulada de las personas de la enunciación yo-tú, y por eso, según él, en el verso de César Vallejo: "Hay golpes en la vida, tan fuertes, yo no sé", la impresión de que el "yo" del poema es el propio Vallejo es una mera ilusión, un perfecto "simulacro": "Ese 'yo' es un 'personaje' del poema y no Vallejo" (p. 32). El Vallejo del poema es "una entidad semántica construida por el lenguaje, cuya existencia adquiere los límites que le fija el texto" (p. 56). Es de esa manera que a lo largo de este ensayo comprenderemos el yo de los poemas analizados. Lo entenderemos como un actor semiótico, distinto del yo del autor. 
En palabras de Breton:

todo conduce a creer... que existe un cierto punto en el espíritu donde la vida y la muerte, lo real y lo imaginario, el pasado y el futuro, lo comunicable y lo incomunicable, lo alto y lo bajo dejan de percibirse contradictoriamente". (Como se citó en Alquié, 1974, pp. 133-134)

La tortuga ecuestre es una notoria demostración de ello, pues establece una relación entre el sustantivo correspondiente a un animal de andar lento con un adjetivo perteneciente, más bien, a animales rápidos como los equinos. Volviendo a "Vienes en la noche con el humo fabuloso de tu cabellera", ese acto de rodar por el cuerpo, en declive, une figuras corporales inferiores con figuras del mundo superiores. Mezcla los pies, que como tales están sobre la tierra, con fenómenos que se desarrollan arriba, en el cielo: las centellas y las constelaciones gemelas. El quiasmo icónico en Un perro andaluz también apela a las "aproximaciones insólitas", solo que de modo descendente: la mano con un agujero, similar al del mesías crucificado que, en vez de expulsar sangre, permite la circulación de animales de superficies terrestres (las hormigas), o la axila femenina, que se convierte, gracias a una disolvencia, en la imagen de un animal que se encuentra en el fondo del mar.

El proceso de iconización, en estos casos, puede ser definido como una "mutación": el cuerpo humano convertido en otra entidad distinta. Así como en La tortuga ecuestre, al igual que en Un perro andaluz, es posible apreciar la forma en la que las figuras corporales y humanas devienen en entidades animales, líquidas o estelares. Hay que precisar que esta mutación no es exclusiva de la literatura y el cine surrealistas. También se puede hallar en una pintura como Construcción blanda con judías hervidas (Premonición de la Guerra Civil) (1936) de Salvador Dalí.

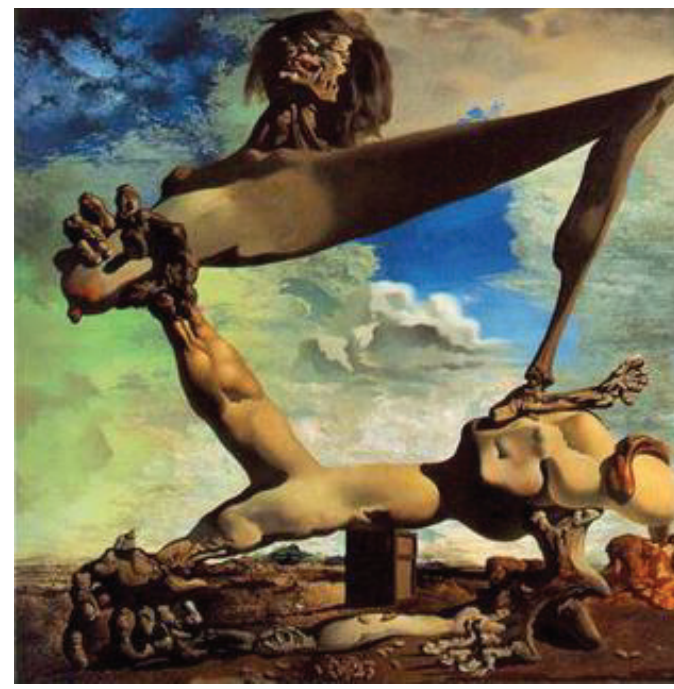

Figura 1. Construcción blanda con judías hervidas (1936) de Salvador Dalí

Fuente: Reproducido de Philadelphia Museum of Art (https://philamuseum. org/collection/object/51315) 
En Construcción blanda..., se identifica una "mutación". El cuerpo se ve fusionado con entidades rocosas o de tierra en la mano ubicada en la esquina inferior izquierda. Tanto dicha mano como el pie que se ve en la otra esquina baja de la pintura no solo se caracterizan por haber adquirido un rol figurativo distinto, de /tronco/, sino que además ejecutan un rol temático distinto, de /sostén/. Son la base sobre la que otras partes del cuerpo se apoyan ${ }^{3}$.

Por todo lo expresado, hallamos en estas expresiones surrealistas una conciencia del quiasmo, en la cual no se puede comprender el cuerpo como un ser disociado del mundo, sino, por el contrario, como un fenómeno integrado, unido, mezclado, "mutado" con él. Este aspecto nos conduce a profundizar en la noción del mundo como ser sensible.

\section{COGIDOS POR EL MUNDO}

Es imposible hablar del quiasmo sin hablar de la "carne del mundo". Sentimos el mundo, pero a la vez el mundo nos siente. Siguiendo a Zilberberg (2016), es posible notar que el autor parte de su óptica semiótica y tensiva para enfatizar en los "modos semióticos", que ahondan en "la relación sujeto/objeto" (p. 15). Asimismo, esto se enlaza con el "modo de existencia", definido a partir de la dinámica entre la "mira" y la "captación" (p. 28). En dicha modalidad, un objeto es un "evento" capaz de captar al sujeto, convertido así en ser que lo padece, afectado por un "sobrevenir": "Para que una magnitud sea recibida como objeto debe, de ser posible, sobrevenir -modo de eficiencia-. Debe captar al sujeto, que se convierte por contigüidad en sujeto del padecer" (Zilberberg, 2016, p. 16). Por ejemplo, el poema "Justicia", escrito por Blanca Varela, permite ejemplificar dicha forma de "captación":

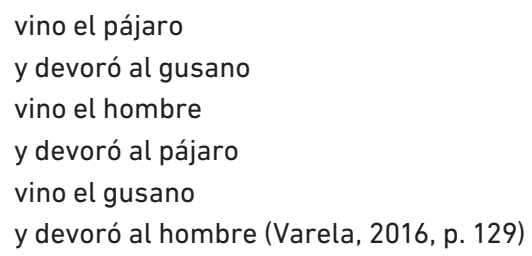

En la obra citada, el gusano es una criatura "captada" por el pájaro y este lo padece, al momento de ser devorado. De la misma manera, el referido pájaro es "captado" por un ser humano que lo padece cuando también es devorado. Llama la atención que, al final

3 Los roles temáticos, atribuidos al actor semiótico, "constituyen la formulación actancial de los temas o de los recorridos temáticos" (Greimas y Courtés, 1990, p. 344). Del mismo modo, tal actor puede estar dotado de roles figurativos, al aparecer "como una figura autónoma del universo semiótico. El actor puede ser [...] figurativo (antropomorfo o zoomorfo)" (Greimas y Courtés, 1992, p. 27). Es común también en el modelo colocar barras diagonales a los costados de los roles temáticos y figurativos. 
del poema, el gusano también ejerza una "captación" sobre el hombre, de forma que este lo padezca, y pueda captarlo súbitamente, como un "sobrevenir". Los versos permiten apreciar la "captación" que describe Zilberberg, y la forma en la que el sujeto funge de objeto y viceversa.

Volviendo a textos surrealistas, la "carne del mundo" en el poema de Moro "Oh furor el alba se desprende de tus labios" se concentra en la figura de la ventana, a través de la cual se une el objeto amado, que la golpea, y el sujeto que padece su presencia, como figura corporal y alucinatoria, tal como se puede apreciar en el siguiente fragmento:

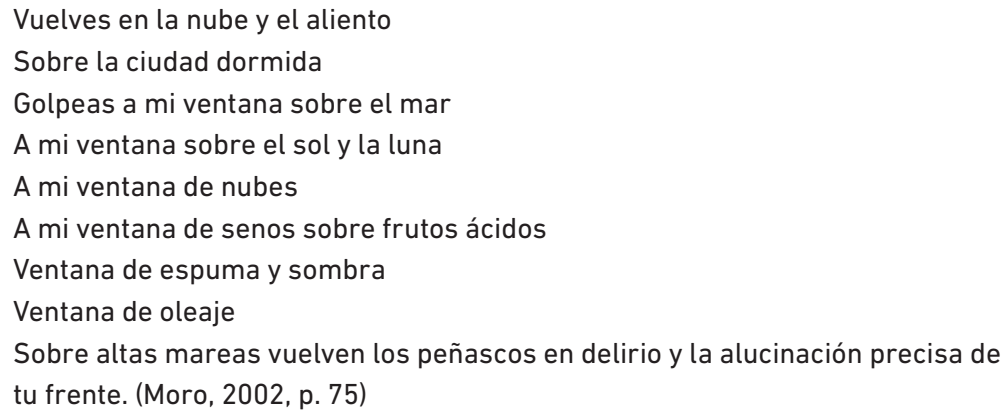

La ciudad dormida, por un lado, remite al estado esencial que refleja el surrealismo, el sueño; por otro, el hecho de que la arquitectura de una ciudad esté caracterizada por ventanas presenta a dicho espacio como uno onírico y coherente con el fenómeno del quiasmo ya apreciado. Es una ventana "golpeada" por el objeto deseado, pero que se coloca en distintas posiciones, tanto inferiores ("sobre el mar") como superiores ("sobre el sol y la luna"). A la vez, es un cuerpo-envoltura.

El cuerpo-envoltura es uno de los tipos de figura icónica del cuerpo planteados por Fontanille (2008), junto al cuerpo-carne, cuerpo-cavidad y cuerpo-punto. Adicionalmente, a cada una de dichas figuras le corresponde un movimiento corporal determinado: "la deformación (movimiento de la envoltura), la moción íntima (movimiento de la carne), la agitación (movimiento del cuerpo-cavidad) y el desplazamiento (movimiento del cuerpopunto)" (Fontanille, 2008, p. 265).

Dicho cuerpo-envoltura es definido como aquel que cuenta con una "red polisensorial y superficial que pone en contacto el Mí (la carne [...]) y el mundo, o más precisamente, que recibe, de un lado, solicitaciones del mundo y, del otro, solicitaciones del Mí" (Fontanille, 2008, p. 192). Como superficie, el cuerpo-envoltura puede ser deformado, y cuenta con dos caras: una cara vuelta hacia el contenido (el continente) y otra cara vuelta hacia el otro plano (la superficie de inscripción). Llegamos así a la representación de la siguiente función semiótica: 


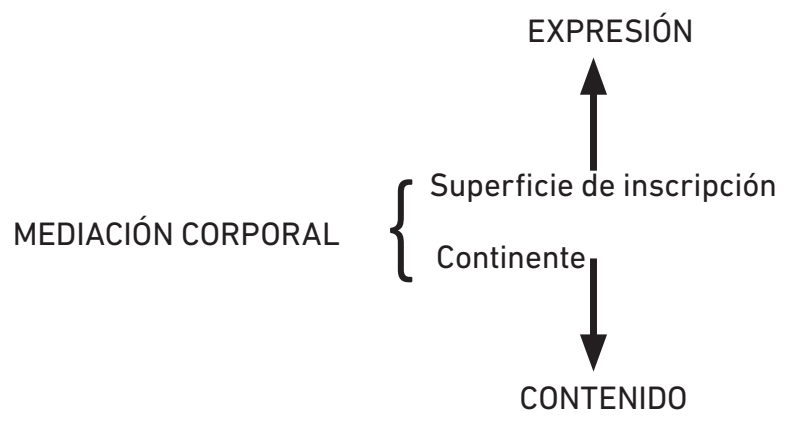

Figura 2. Las dos caras del cuerpo-envoltura

Fuente: Reproducido de Fontanille (2008, p. 208)

Con el fin de entender mejor lo planteado por Fontanille, apreciemos algunos versos de Trilce de César Vallejo. En el poema XXVI, un cuerpo masculino se "deforma" hasta adquirir rasgos femeninos. Es una superficie en la que se "inscriben" glándulas mamarias: “jHembra se continúa el macho, a raíz de probables senos, y precisamente a raíz de cuanto no florece!" (Vallejo, 2015). Además, posee las cualidades de una "envoltura", al actuar como un continente que circunda un contenido pasional: "Tal siento ahora al meñique... Y me inspira rabia" (Vallejo, 2015).

Volvamos al surrealismo del poema de Moro. La figura de la ventana "envuelve" esencialmente tres isotopías figurativas": líquida (/nubes/, /espuma -en complemento con la figura /sombra/-, /oleaje/), vegetal (/frutos ácidos/) y corporal (/senos/). Estas isotopías abarcan figuras antecedidas por la preposición de, que puede señalar posesión (ventana de nubes, ventana de senos sobre frutos ácidos, ventana de espuma y sombra, ventana de oleaje).

Al final del fragmento que incluimos de "Oh furor el alba se desprende de tus labios", estados de confusión mental se asocian a una figura líquida y otra mineral: /altas mareas/ y /peñascos/ ("Sobre altas mareas vuelven los peñascos en delirio"), pero también a una zona del rostro, la /frente/ ("la alucinación precisa de tu frente"), así como al /rostro/ al final del siguiente fragmento:

4 En numerosas ocasiones, la isotopía es definida por medio de la repetición o redundancia de figuras o temas. De esta manera, posibilita que de un mismo texto surjan distintas líneas de interpretación. En palabras de Quezada Macchiavello (1992), "este término: isotopía, es muy cómodo para reconocer y describir la relativa homogeneidad de un discurso, sus posibles líneas de lectura. La isotopía es ese plano común que posibilita, pues, la coherencia global de cualquier enunciación. Dicho plano se entiende a partir de la permanencia de algunos rasgos mínimos" (p. 317). 
Sobre altas mareas tu frente y más lejos tu frente y la luna es tu frente y un barco sobre el mar y las adorables tortugas como soles poblando el mar y las algas nómadas y las que fijas soportan el oleaje y el galope de nubes persecutorias el ruido de las conchas las lágrimas eternas de los cocodrilos el paso de las ballenas la creciente del Nilo el polvo faraónico la acumulación de datos para calcular la velocidad del crecimiento de las uñas en los tigres jóvenes la preñez de la hembra del tigre el retozo del albor de los aligátores el veneno en copa de plata las primeras huellas humanas sobre el mundo tu rostro tu rostro tu rostro. (Moro, 2002, p. 75)

En el poema, la isotopía figurativa corporal, compuesta por las figuras /frente/ y /rostro/, al igual que en el anterior fragmento, se cruza con una isotopía figurativa líquida: /altas mareas/, /barco/, /mar/, /algas/, /oleaje/, /nubes/, /conchas/, /lágrimas/, /ballenas/, /Nilo/ y /veneno en copa de plata/. En ese sentido, lo que podemos apreciar es que la /frente/ y el /rostro/, al igual que la /ventana/, son cuerpo-envoltura, se estructuran como continente de un contenido acuoso. Pero, además, dichas figuras corporales abarcan isotopías de carácter tanto animal (/tigres jóvenes/, /la hembra del tigre/, /aligátores/) como terrenal (/polvo faraónico/, /primeras huellas humanas/). Incluso la isotopía corporal está acentuada por la repetición de la palabra /rostro/ ("tu rostro tu rostro tu rostro"). Todos estos cruces isotópicos muestran que tanto las figuras del cuerpo como las objetuales, esencialmente la /ventana/, de alguna manera una figura que se establece como extensión del cuerpo "golpeado" por el objeto de deseo ("Golpeas a mi ventana sobre el mar / A mi ventana sobre el sol y la luna / A mi ventana de nubes / A mi ventana de senos sobre frutos ácidos"), son el mundo: el sol, el mar, la tierra, la luna, los animales... Solo cabe el quiasmo para la comprensión del cuerpo y el mundo.

En términos de Zilberberg, la /ventana/ es un objeto que siente el mundo. Y si exploramos otro poema de Moro como "Batalla al borde de una catarata", el mundo es cuerpo y objeto que se aproxima al yo que "habla" en el poema, como parte de una extremidad superior que posee la apariencia de una cortina alojada entre un espacio urbano y otro mítico: "Para explicarme en letra muerta las prolongaciones misteriosas de tus manos que vuelven con el aspecto amenazante de un cuarto modesto con una cortina roja que se abre ante el infierno" (Moro, 2002, p. 82). Ese mundo también experimenta una "mutación" en la cual una isotopía corporal se cruza con una isotopía celestial, en la que figuras como /espalda/, /vientre/ o /muslo/ se entremezclan con el /diluvio/, el /aluvión/ o las /centellas/: "Tu espalda de diluvio / Tu vientre de aluvión un muslo de centellas" (Moro, 2002, p. 82).

Con relación al objeto en La tortuga ecuestre, podemos decir lo mismo de las sogas que coge el personaje masculino en una de las más famosas secuencias de Un perro andaluz. Una vez que acosa a una mujer, toma del suelo dos sogas. Dicho hombre se ve 
impedido de acercarse a ella porque dichas cuerdas están sujetadas a algunos objetos o seres humanos: dos maristas, y dos pianos de cola con burros podridos encima. En su estudio del cortometraje de Buñuel, Talens (2010) interpreta que tales figuras encarnan una burguesía que reprime lo sexual:

Hasta qué punto la violencia del hombre debe tener alguna explicación a los ojos de la desconcertada protagonista, justificaría la presencia de esta serie de planos donde los pianos de cola, los maristas y los burros muertos pueden muy bien aludir, de modo indirecto, a los despojos de una cultura decadente como la burguesa, donde arte, religión y podredumbre se dan la mano en la articulación de un sistema de valores contra el que Buñuel siempre ha arremetido con crueldad, pero fundamentalmente, y ello es lo importante aquí, donde la posibilidad misma de asociar sexualidad, brutalidad y represión no resulta gratuita, por cuanto dicha asociación es una de las bases de su existencia. (p. 102)

En ese sentido, el personaje masculino coge las sogas, pero ellas son la prolongación de un mundo que siente su deseo sexual y que lo condena, lo limita, lo cohíbe, tal como lo afirma Talens (2010), desde su arte, religión y podredumbre. Estamos ante objetos que captan (o capturan) al sujeto. Estos son la "carne del mundo" en la que ese mundo burgués siente la desenfrenada sexualidad del personaje y este siente el peso represor de dicho mundo que reacciona ante su avance hacia la mujer.

Además de las sogas, otro objeto que al igual que la ventana de Moro capta al sujeto es la pared. Después de no lograr poseer a la mujer, se ve al personaje masculino estático, quieto, echado en una cama. Es una imagen que se intercala con otra en la cual se aprecia una pared con dos orificios, a través de los cuales dos brazos sacuden un cocktail. Es evidente la connotación masturbatoria del encuadre, pero a la vez la aparición de la pared como objeto que "capta" ese deseo sexual que el hombre no puede cumplir.

Es un deseo sexual captado no solo por objetos como la pared, sino también por animales, como las hormigas, que aparecen por el orificio de la mano del hombre justo cuando la mujer trata de contener su acoso empujando una puerta. La imagen de él es cuerpo-envoltura: continente de un contenido animal que sale por un orificio de la mano, y dicho contenido se "inscribe" en la "superficie" de dicha mano para expresar la lujuria que invade al personaje.

Los objetos en Un perro andaluz también pueden captar el deseo violento de los personajes. Unos cuadernos que son cogidos por un personaje sienten en el contacto con las manos de él su deseo asesino y así se convierten en pistolas con las cuales asesina a otro. Este, una vez que recibe los disparos, y se desvanece, aparece a través de una ruptura de raccord, de una interrupción de la continuidad de los encuadres, ya no en el ambiente cerrado de una casa, sino en un bosque. Mientras cae lentamente en el jardín, sus manos van rozando la espalda de una mujer semidesnuda, que está de espaldas 
a nuestra mirada. Tomando en cuenta a dicho personaje masculino, la imposibilidad de sentir ante la irrupción de la muerte implica automáticamente la desaparición del mundo, y en específico de ese mundo femenino tan inalcanzable como totalidad, sintetizado en la visión de aquella fémina que se esfuma ante nuestros ojos.

Inclusive la visión en un plano de detalle de una mariposa de la muerte que reposa en un muro (lepidóptero conocido por tener en su dorso una superficie semejante a una calavera), emerge como una imagen premonitoria que siente lo que ocurrirá en el último encuadre de Un perro andaluz: la aparición de dos personajes inertes y enterrados a medio cuerpo en la arena de una playa. Tanto los objetos como los animales captan al sujeto, su deseo al igual que su destino.

Es importante agregar que este último aspecto podemos identificarlo en otros discursos surrealistas, más allá de los literarios o cinematográficos. En la pintura de René Magritte Le Fils de l'homme (1964), encontramos la imagen de un hombre con un rostro que se ve oculto tras una manzana verde, que parece flotar a la altura justamente de su cabeza. El cuerpo del personaje se ve inmóvil. Más bien, la fruta se ve alzada en el aire, como dirigida hacia su cara. Cierto es que hablar de la relación facial de un ser humano con una manzana implica referir las posibilidades de sentirla: visual, táctil, gustativa y olfativamente. La pintura de Magritte hace el mismo recorrido sensorial, pero de manera inversa: la manzana se acerca al personaje, lo capta y se coloca dispuesta a ser sentida.

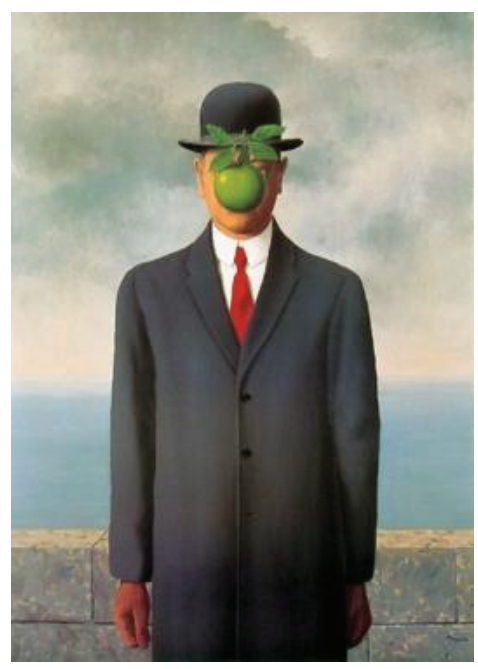

Figura 3. Le Fils de l'homme (1964) de René Magritte

Fuente: Reproducido de Wikipedia

(https://en.wikipedia.org/wiki/File:Magritte_TheSonOfMan.jpg) 


\section{IDEAS FINALES: SOBRE ORÍGENES Y PROLONGACIONES}

La iconicidad posibilita identificar en discursos poéticos y cinematográficos surrealistas una conciencia del quiasmo. La tortuga ecuestre de César Moro y Un perro andaluz de Luis Buñuel son casos representativos de esto. En ese sentido, cabe recordar un poema de André Breton llamado "La unión libre" ("L'union libre"), escrito en 1931:

Mi mujer cabellera de lumbre de leño

Pensamientos de relámpagos de calor

Talle de reloj de arena

Mi mujer talle de nutria bajo los dientes del tigre

Mi mujer boca de escarapela y de ramillete de estrellas de última magnitud

Dientes de huellas de ratón blanco sobre la tierra blanca

Lengua de ámbar y de vidrio frotados

Mi mujer lengua de hostia apuñalada

Lengua de muñeca que abre y cierra los ojos

Lengua de piedra increíble

Mi mujer pestañas de palotes de escritura de niño

Cejas de borde de nido de golondrina

Mi mujer sienes de pizarra de invernadero

$Y$ de vapor en los cristales

Mi mujer hombros de champaña

$Y$ de fontana con testas de delfines bajo el hielo

Mi mujer muñecas de fósforos

Mi mujer dedos de azar y de as de corazón

Dedos de heno segado

Mi mujer axilas de marta y de fasces

De noche de San Juan

De alheña y de nido de escalares

Brazos de espuma de mar y de esclusa

$Y$ de alianza de trigo y de molino

Mi mujer piernas de fuegos artificiales

\section{$[\ldots]$}

Mi mujer nalgas de greda y de amianto

Mi mujer nalgas de dorso de cisne

Mi mujer nalgas de primavera

Sexo de gladiolo

Mi mujer sexo de yacimiento y de ornitorrinco

Mi mujer sexo de alga y de bombones antiguos

Mi mujer sexo de espejo

Mi mujer ojos llenos de lágrimas

Ojos de panoplia violeta y de agua imantada

Mi mujer ojos de sabana

Mi mujer ojos de agua para beber en prisión 
Mi mujer ojos de leño siempre bajo el hacha

Ojos de nivel de agua de nivel de aire de tierra y de fuego ${ }^{5}$ (Breton, 1993, pp. 85-87)

"La unión libre" presenta los siguientes versos: "Mi mujer ojos de leño siempre bajo el hacha / Ojos de nivel de agua de nivel de aire de tierra y de fuego". Se aprecia en el final del poema cómo Breton antecede esa comprensión surreal del cuerpo ya analizada, y de qué manera dicho texto encarna un cuerpo-envoltura, expresamente referido como femenino. Los ojos quedan "inscritos" en dicha "superficie", bajo una condición objetual, sólida (son "de lecho siempre bajo el hacha"), y son "continente" de los cuatro elementos de la naturaleza: el agua, la tierra, el aire y el fuego.

5 El poema, en su idioma original:

"Ma femme à la chevelure de feu de bois

Aux pensées d'éclairs de chaleur

À la taille de sablier

Ma femme à la taille de loutre entre les dents du tigre

Ma femme à la bouche de cocarde et de bouquet d'étoiles de dernière grandeur

Aux dents d'empreintes de souris blanche sur la terre blanche

À la langue d'ambre et de verre frottés

Ma femme à la langue d'hostie poignardée

À la langue de poupée qui ouvre et ferme les yeux

À la langue de pierre incroyable

Ma femme aux cils de bâtons d'écriture d'enfant

Aux sourcils de bord de nid d'hirondelle

Ma femme aux tempes d'ardoise de toit de serre

Et de buée aux vitres

Ma femme aux épaules de champagne

Et de fontaine à têtes de dauphins sous la glace

Ma femme aux poignets d'allumettes

Ma femme aux doigts de hasard et d'as de coeur

Aux doigts de foin coupé

Ma femme aux aisselles de martre et de fênes

De nuit de la Saint-Jean

De troène et de nid de scalares

Aux bras d'écume de mer et d'écluse

Et de mélange du blé et du moulin

Ma femme aux jambes de fusée

[...]

Ma femme aux fesses de grès et d'amiante

Ma femme aux fesses de dos de cygne

Ma femme aux fesses de printemps

Au sexe de glaïeul

Ma femme au sexe de placer et d'ornithorynque

Ma femme au sexe d'algue et de bonbons anciens

Ma femme au sexe de miroir

Ma femme aux yeux pleins de larmes

Aux yeux de panoplie violette et d'aiguille aimantée

Ma femme aux yeux de savane

Ma femme aux yeux d'eau pour boire en prison

Ma femme aux yeux de bois toujours sous la hache

Aux yeux de niveau d'eau de niveau d'air de terre et de feu". 
En el poema de Breton las figuras corporales tienden a funcionar como objetos de condición concreta ("cabellera de lumbre de leño", "Talle de reloj de arena", "lengua de hostia apuñalada", "Lengua de muñeca que abre y cierra los ojos", "pestañas de palotes de escritura de niño", "sienes de pizarra de invernadero", "muñecas de fósforo", "dedos de azar y de as de corazón", "Ojos de panoplia violeta", "ojos de sabana") o como componentes de la naturaleza ("Lengua de ámbar", "Dedos de heno segado", "axilas de marta y de fasces", "sexo de gladiolo", "Ojos [...] de agua imantada", "ojos de agua para beber en prisión"), o como extensiones de lo animal ("talle de nutria bajo los dientes del tigre", "Cejas de borde de nido de golondrina", "nalgas de dorso de cisne", "sexo de yacimiento y de ornitorrinco"). Por medio del cuerpo de la mujer, se iconizan los denominados reinos animal, vegetal y mineral.

En la misma línea, el cuerpo-envoltura de "La unión libre" posee atributos aéreos, marinos y terrenales: "Mi mujer boca de escarapela y de ramillete de estrellas de última magnitud", "Dientes de huellas de ratón blanco sobre la tierra blanca”, "Lengua de piedra increíble", "Mi mujer hombros de champaña / Y de fontana con testas de delfines bajo el hielo", "Mi mujer [...] De noche de San Juan", "Brazos de espuma de mar y de esclusa / Y de alianza de trigo y molino", "Mi mujer piernas de fuegos artificiales", "Mi mujer nalgas de greda y de amianto", y "Mi mujer sexo de alga y de bombones antiguos".

En los versos citados la boca de la mujer forma parte de un orden estelar, los dientes se encuentran vinculados a lo terrenal, la lengua se caracteriza por su condición mineral, los hombros y los brazos son de una dimensión acuática o vegetal, las piernas se elevan con fuerza luminosa y origen celestial, las nalgas provienen de lo terrenal y mineral, el sexo se encuentra ubicado dentro del mar, y los ojos forman también parte de un orden líquido. El cuerpo "muta" con todo aquello que lo rodea.

De esta forma, la mujer no solo es cuerpo, sino también mundo en que el yo se encuentra presente. Ella es una corporeidad que se halla desde el nivel de las aguas y la tierra hasta el del cielo. Se encuentra fragmentada y a la vez se aloja en la espacialidad absoluta del mundo. El yo del poema siente el mundo, pero este, en términos de Zilberberg, es un "evento" que capta a dicho yo, sensorialmente.

En ese sentido, La tortuga ecuestre demuestra ser una obra representativa de cómo suele funcionar el cuerpo en la iconicidad de la poesía surrealista. Justamente, Fernández Cozman (2003), respecto de la obra de Moro, Éluard y Breton, identifica una recurrente dinámica cosmogónica:

En la lírica surrealista tenemos con frecuencia el funcionamiento de cosmogonías. Por ejemplo, las Cartas, de César Moro, donde Antonio es visto como un dios que organiza el universo, pues el semen de Antonio hace fecundar a las estrellas, perspectiva cósmica que materializa un discurso sobre el origen del mundo. La poesía de Éluard es testimonio irrefutable de una óptica cosmogónica; verbigracia, 
uno de sus poemas dice así: "La tierra es azul como una naranja / [...] Las avispas florecen verdes / El alba transcurre en torno del cuello / Un collar de ventanas / Unas alas cubren las hojas". En "Unión libre", célebre poema de Breton, existe también la construcción de una cosmogonía basada en la figura de una mujer que es una síntesis de todo el universo. (p. 52)

En Un perro andaluz, la iconización del quiasmo se comprende a través de una "carne del mundo". Esta es manifestada a través de un personaje y todo lo que lo rodea: se encuentra plasmada en figuras corporales mundanas, caracterizadas por un impulso sexual que se encuentra limitado. Una secuencia emblemática es la del hombre que ansía poseer a la mujer, pero le es imposible saciar dicho deseo debido a unas sogas enlazadas a unos pianos de cola (que tienen encima dos burros podridos) y a dos maristas. Estamos así ante objetos que representan la represión del cuerpo, y no su explosión erótica (rasgo constante en el cine posterior de Buñuel, que no se encorseta en las coordenadas del surrealismo, sino que guarda características de la vanguardia).

Es posible encontrar figuras que restringen el deseo erótico en un cortometraje como La concha y el clérigo (La coquille et le clergyman, 1928) de Germaine Dulac, con guion de Antonin Artaud, que anticipó los rasgos audiovisuales del surrealismo. La película se acerca al aparente triángulo amoroso de un clérigo, un general y su esposa. Como en Un perro andaluz, el cuerpo recorre una trayectoria a la manera de una "aproximación insólita", incompatible con el entorno o con lo humanamente posible: el clérigo se desplaza por la calle gateando o se moviliza con una velocidad imposible al correr hacia la mujer que desea. La concha y el clérigo, además, es una película que en muchas oportunidades transgrede la continuidad narrativa: un encuadre puede aparecer sin ser la consecuencia lógica y temporal del anterior (la secuencia de los puños que golpean una superficie, alusiva al onanismo, es parecida al súbito encuadre que aparece en la película de Buñuel que muestra unas manos que sacuden un cocktail). Por otro lado, en la escena en la que el clérigo estrangula al general, el rostro de este adquiere las características de una envoltura de inscripción geométrica. Se fragmenta en imágenes rectangulares. Así, estamos ante una mutación icónica, típica del surrealismo.

Fernando de Szyszlo realizó un cortometraje en 1952, Esta pared no es medianera, cuyas imágenes recuerdan al cortometraje de Buñuel, como aquella de una pareja que recorre la orilla de una playa. También se encuentra un hombre que en el interior de una casa va hacia una mujer que se balancea en una silla y descubre a continuación que ella es una calavera. Asimismo, vemos cómo el personaje se halla imposibilitado de salir de la casa, incapaz de aproximarse a una fémina que camina cerca, mientras grita tras las barras de una ventana. El deseo del cuerpo se ve limitado por objetos materiales o incluso por la misma muerte, al igual que en Un perro andaluz. Si los objetos actúan como "carne del mundo", al ser sentidos por el sujeto y a la vez sentir y contener el deseo hacia una mujer, la muerte es un evento que sorprende, impacta, conmociona al cuerpo: sobreviene. 
Estamos ante posibilidades cinematográficas e icónicas del quiasmo que también están presentes en otra película abiertamente surrealista del realizador español, La edad de oro (L'âge d'or, 1930). En ella, la simbología religiosa acentúa aún más la represión sexual del cuerpo. Ello puede apreciarse en una secuencia en la cual unos personajes obstaculizan la relación sexual de una pareja, cerca de una playa. Quienes los retienen lo hacen después de haber saludado a unos cadáveres con trajes litúrgicos que se encuentran sobre unas rocas. El hombre y la mujer que no pueden concretar su deseo sienten la represión en la separación de sus cuerpos. El mundo que los rodea y condena, por su parte, los siente y a la vez se siente amenazado, hasta agónico, tal como se refleja en aquellos restos óseos que llevan prendas propias de autoridades de la Iglesia católica. Este tipo de imágenes también las podemos apreciar en otras películas de Buñuel que no son íntegramente surrealistas, como Ensayo de un crimen (1955), El ángel exterminador (1962), Bella de día (Belle de jour, 1967), entre otras.

El enfoque del quiasmo nos ha permitido encontrar puntos en común entre la poesía y el cine surrealistas, a través de esa reversibilidad abordada en la figura icónica del cuerpo-envoltura; de esa iconización del mundo como un evento corporal que capta al sujeto, que aprehende al yo; y de esa "carne del mundo" que en el proceso icónico llamado "mutación" exhibe al cuerpo y al mundo como seres fusionados e indivisibles. También hemos podido identificar diferencias: el desenfreno mítico del cuerpo, por un lado, y la represión sexual, por otro, lo que merece alguna exploración futura y mayor.

\section{REFERENCIAS}

Alquié, F. (1974). Filosofía del surrealismo. Barral Editores.

Abbagnano, N. (2008). Diccionario de filosofía. Fondo de Cultura Económica.

Blanco, D. (2009). Vigencia de la semiótica y otros ensayos. Universidad de Lima, Fondo Editorial.

Breton, A. (1993). Poemas. Jaime Campodónico/Editor.

Courtés, J. (1997). Análisis semiótico del discurso. Gredos.

Coyné, A. (2015). Introducción de los coordinadores. En Moro, C., Obra poética completa (pp. XLVI-XLVIII). Alción Editora.

Dalí, S. (1936). Construcción blanda con judías hervidas (Premonición de la Guerra Civil) [óleo sobre lienzo]. Philadelphia Museum of Art. https://philamuseum.org/collection/ object/51315

Fernández Cozman, C. (2003). Las ínsulas extrañas de Emilio Adolfo Westphalen. Universidad Nacional Mayor de San Marcos, Fondo Editorial; Dedo Crítico. 
Fernández Cozman, C. (2012). César Moro, ¿un antropófago de la cultura? Revuelta Editores.

Fontanille, J. (2008). Soma y sema. Figuras semióticas del cuerpo. Universidad de Lima, Fondo Editorial.

Garrido Gallardo, M. A. (2009). Fundamentos del lenguaje literario. En Garrido Gallardo, M. A. (Dir.), El lenguaje literario. Vocabulario crítico (pp. 9-236). Editorial Síntesis.

Greimas, A. J., y Courtés, J. (1990). Semiótica: diccionario razonado de la teoría del lenguaje. Gredos.

Lefort, D. (2015). Introducción de los coordinadores. En Moro, C., Obra poética completa (pp. XXIX-XLII). Alción Editora.

Magritte, R. (1964). Le fils de l'homme [Óleo sobre lienzo]. Wikipedia. https://en.wikipedia. org/wiki/File:Magritte_TheSonOfMan.jpg

Merleau-Ponty, M. (1993). Fenomenología de la percepción. Planeta-Agostini.

Merleau-Ponty, M. (2010). Lo visible y lo invisible. Ediciones Nueva Visión.

Moro, C. (2002). Prestigio del amor. Pontificia Universidad Católica del Perú.

Pellegrini, A. (2012). Antología de la poesía surrealista. Argonauta.

Quezada Macchiavello, Ó. (1992). Semiótica generativa. Bases teóricas. Universidad de Lima, Fondo Editorial.

Ramírez, M. T. (2013). La filosofía del quiasmo. Introducción al pensamiento de Maurice Merleau-Ponty. Fondo de Cultura Económica.

Richardson, M. (2006). Surrealism and Cinema. Berg.

Talens, J. (2010). El ojo tachado. Cátedra.

Vallejo, C. (2015). Obras. Colección integral. Amazon.com Services LLC.

Varela, B. (2016). Poesía reunida 1949-2000. Casa de Cuervos/Sur Librería Anticuaria.

Zilberberg, C. (2016). De las formas de vida a los valores. Universidad de Lima, Fondo Editorial. 